\title{
The relationship between carbon dioxide concentration and visitor numbers in the homothermic zone of the Balcarka Cave (Moravian Karst) during a period of limited ventilation
}

\author{
Marek Lang ${ }^{1}$, Jiři Faimon ${ }^{1}$, and Camille Ek $^{2}$ \\ ${ }^{1}$ Department of Geological Sciences, Faculty of Sciences, Masaryk University, Kotlářská 2, 61137 Brno, Czech Republic \\ ${ }^{2}$ Department of Geology, University of Liège, 4000 Liège, Belgium
}

\begin{abstract}
The evolution of $\mathrm{CO}_{2}$ levels with and without human presence was studied in a selected site (Gallery Chamber) of the homothermic zone of the Balcarka Cave (Moravian Karst, Czech Republic) during the fall, a period of limited ventilation. There were recognized various factors controlling the cave $\mathrm{CO}_{2}$ levels under different conditions in the exterior and interior. When visitors were absent, $\mathrm{CO}_{2}$ levels were controlled by the advective $\mathrm{CO}_{2}$ fluxes linked to cave airflows and reaching up to $\sim 1.5 \times 10^{-3} \mathrm{~mol} \mathrm{~s}^{-1}$. These fluxes exceed by orders of magnitude the exchanged diffusive fluxes (up to $4.8 \times 10^{-8} \mathrm{~mol} \mathrm{~s}^{-1}$ ) and also the natural net flux (from $1.7 \times 10^{-6}$ to $6.7 \times 10^{-6} \mathrm{~mol} \mathrm{~s}^{-1}$ ) imputing given chamber directly from overburden. The natural net flux, normalized to unitary surface area, was estimated to be $2.8 \times 10^{-8}$ to $1.1 \times 10^{-7} \mathrm{~mol} \mathrm{~m}^{-2}$ $\mathrm{s}^{-1}$, based on a perpendicular projection area of the chamber of $\sim 60 \mathrm{~m}^{2}$. When visitors were present, the anthropogenic $\mathrm{CO}_{2}$ flux into the chamber reached up to $3.5 \times 10^{-3} \mathrm{~mol} \mathrm{~s}^{-1}$, which slightly exceeded the advective fluxes. This flux, recalculated per one person, yields the value of $6.7 \times 10^{-5} \mathrm{~mol} \mathrm{~s}^{-1}$. The calculations of reachable steady states indicate that anthropogenic fluxes could almost triple the natural $\mathrm{CO}_{2}$ levels if visitors stayed sufficiently long in the cave.
\end{abstract}

Keywords: $\quad$ anthropogenic and natural $\mathrm{CO}_{2}$; cave ventilation; flux; dynamic model; temperature difference Received 11 July 2014; Revised 30 January 2015; Accepted 2 March 2015

\begin{abstract}
Citation: Lang M., Faimon J. and Ek C., 2015. The relationship between carbon dioxide concentration and visitor numbers in the homothermic zone of the Balcarka Cave (Moravian Karst) during a period of limited ventilation. International Journal of Speleology, 44 (2), 167-176. Tampa, FL (USA) ISSN 0392-6672 http://dx.doi.org/10.5038/1827-806X.44.2.6
\end{abstract}

\section{INTRODUCTION}

Carbon dioxide $\left(\mathrm{CO}_{2}\right)$ is a key component controlling the karst processes such as limestone dissolution and calcite speleothem growth (Dreybrodt, 1999). The driving force for the latter process is the difference in the $\mathrm{CO}_{2}$ partial pressure between (1) the soil/ upper epikarst, ${ }^{\left({ }^{(E)}\right)} \mathrm{P}_{\mathrm{CO}_{2}}$, and (2) the cave atmosphere, ${ }^{(\mathrm{C})} \mathrm{P}_{\mathrm{CO}_{2}}$ (White, 1998; Ford \& Williams, 2007). Whereas a high ${ }^{(\mathrm{EK})} \mathrm{P}_{\mathrm{CO}_{2}}$ (Fairchild et al., 2000; Faimon et al., 2012a) controls saturation of percolating water with respect to the calcite, the lower ${ }^{\left({ }^{C}\right)} \mathrm{P}_{\mathrm{CO}_{2}}$ is responsible for dripwater degassing (releasing of the $\mathrm{CO}_{2}$ excess) (Holland et al., 1964).

The instantaneous $\mathrm{CO}_{2}$ concentration in the cave atmosphere is the balance of the input and output fluxes. The input $\mathrm{CO}_{2}$ flux may generally include the direct natural fluxes associated with (i) the diffusion from soils/epikarst, (ii) dripwater degassing (Bourges et al., 2001), perhaps (iii) microbial decay of organic matter in cave sediments, and (iv) the transport of endogenous $\mathrm{CO}_{2}$ in geologically active regions (Batiot-
Guilhe et al., 2007). The indirect $\mathrm{CO}_{2}$ fluxes can be derived from air advection from (v) adjacent cave passages/epikarst, or e.g. (vi) a cave river and conduit flow. The anthropogenic flux is connected with (vii) the exhaling of cave visitors (Faimon et al., 2006; Milanolo $\&$ Gabrovšek, 2009). The output flux is linked with cave airflow and controlled by cave ventilation (Spötl et al., 2005; Banner et al., 2007; Baldini et al., 2008; Fernández-Cortes et al., 2009).

The cave airflow depends on (1) the cave geometry and (2) the pressure difference resulting from contrasting air densities (de Freitas et al., 1982). Since density is particularly a function of temperature, cave airflows are mostly related to the temperature difference $\Delta \mathrm{T}=\mathrm{T}_{\text {exterior }}-\mathrm{T}_{\text {cave }}$ (where $\mathrm{T}_{\text {exterior }}$ is external air temperature and $\mathrm{T}_{\text {cave }}$ is cave air temperature $\left[{ }^{\circ} \mathrm{C}\right]$ ) (de Freitas et al., 1982; Baker \& Genty, 1998; Pflitsch \& Piasecki, 2003; Russell \& MacLean, 2008; Kowalczk \& Froelich, 2010; Faimon et al., 2012b). A theoretical background on cave air circulation was given by Cigna (1968) and Wigley \& Brown (1971). Based on their geometry, caves may be sorted into two extreme 
groups: (1) static caves with one entrance and (2) dynamic caves with two or more entrances at different altitudes (Geiger, 1966; Bögli, 1978). Whereas the static caves are ventilated for half of the season, the dynamic caves ventilate during the whole year by a so-called chimney effect. The transition between static caves and dynamic caves is represented by a statodynamic cave, defined by more than one entrance at the same altitude (Luetscher \& Jeannin, 2004b). Some parts of the cave have features of a static cave, whereas other parts behave as a dynamic cave. If $\Delta \mathrm{T}<0$, upward airflows occur in the cave, i.e., external air enters the cave at the lower entrance and flows out from the cave by the upper entrance. This regime is called the upward airflow ventilation mode (UAF mode). If $\Delta \mathrm{T}>0$, cave airflows move in the opposite way. In this case, we talk about the downward airflow ventilation mode (DAF mode) (see Faimon et al., 2012a for details). According to the extent of temperature variations in the cave environment, (1) heterothermic zones (passages closer to cave entrances) and (2) homothermic zones (deeper cave passages) are defined (Luetscher \& Jeannin, 2004b). Whereas the heterothermic zone is strongly influenced by external temperature, the homothermic zone is characterized by temperature stability. Two different ventilation periods can be distinguished in cave: (i) the period of active ventilation and (ii) the period of limited ventilation (Faimon et al., 2012b). In the active ventilation period, the duration of the individual ventilation mode exceeds the air residence time in the cave. In such a case, the air in the whole cave is completely exchanged. In the limited ventilation period, the duration of the actual ventilation mode is shorter than the air residence time in the cave. Then the direction of the airflow turns before the cave air is completely replaced by air from the external atmosphere (only the cave-entering passages are ventilated). Previous works on anthropogenically-impacted cave $\mathrm{CO}_{2}$ were presented by, e.g., Pulido-Bosch et al. (1997), Song et al. (2000), Faimon et al. (2006), Liñán et al. (2008),

Fernández-Cortes et al. (2009), Milanolo \& Gabrovšek (2009) or Lario \& Soler (2010). In this work, we focus on the anthropogenically-impacted $\mathrm{CO}_{2}$ in the homothermic zone of the Balcarka Cave, a dynamic cave in the Moravian Karst (Czech Republic). The study was conducted when the ventilation modes changed diurnally and when the cave persisted in the period of limited ventilation. The goal of this work was to propose the dynamic model that would simulate evolution of cave $\mathrm{CO}_{2}$ levels based on routinely available data: temperatures and visitor numbers. The model aims at contributing to a better knowledge of the parameters controlling $\mathrm{CO}_{2}$ levels in a visiting cave under specific conditions of changing ventilation. Overall, the article could help in better understanding recent karst processes.

\section{SITE OF STUDY}

The site of study, the Balcarka Cave, is situated in the northern part of the Moravian Karst near the village of Ostrov u Macochy (Faimon et al., 2012c). The sketch map of the cave with characteristic sites and their positions at different altitudes is illustrated in Fig. 1a. The cave was formed in the Devonian limestone of the Macocha Formation. It consists of two levels of narrow corridors, totaling about $350 \mathrm{~m}$ in length with chambers rich in speleothem formations. The height distance between both cave levels is about $20 \mathrm{~m}$. The overburden thickness reaches up $\sim 40 \mathrm{~m}$ (Fig. 1b). The same distance is probably between the levels of the lowest and highest openings. The complex cave geometry with three known entrances and more hidden openings at different altitudes ensures the dynamic behavior of air circulation. The Gallery Chamber in deeper cave passages (in the second cave level) was chosen as the monitoring site (Fig. 1a).
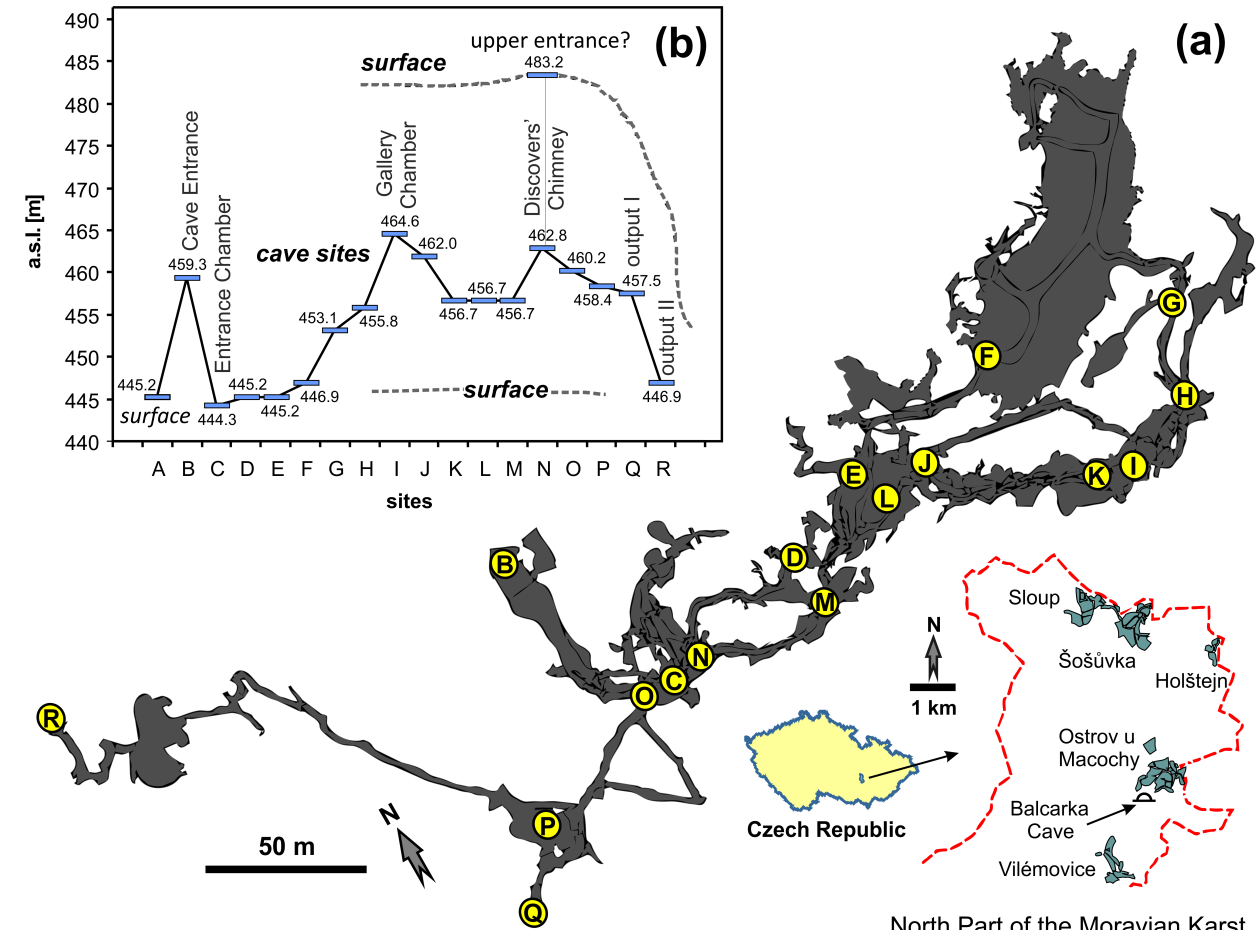

North Part of the Moravian Karst

Fig. 1. Balcarka Cave: the sketch map with its position (a) and the altitude diagram of the individual cave passages (b). The letters denote the monitoring sites from the diagram.

The site is part of the homothermic zone. The chamber volume was estimated to $\sim 150 \mathrm{~m}^{3}$. The cave is seasonally open to tourists with a total attendance of 30,000 to 40,000 persons per year. In the area above the Balcarka Cave, three soil types were identified: Anthrosol, lithic Leptosol, and brown rendzic Leptosol based on the vegetation such as pastures, mixed forest, and karst meadows, respectively (see Faimon et al., 2012c for details). The annual temperature of the external atmosphere at the given site is of $\sim 8^{\circ} \mathrm{C}$. The total annual precipitation is $\sim 700 \mathrm{~mm}$. 
Data were collected during three monitoring campaigns between September and November 2013. A monitoring schedule is given in Table 1 . In addition to the number of visitors, the cave $\mathrm{CO}_{2}$ concentrations and the temperatures of cave air and external air were monitored. Airflow velocities were calculated from the temperature differences (see Faimon \& Lang, 2013). Airflow direction was deduced from the sign

Table 1. Monitoring schedule (Balcarka Cave, Moravian Karst).

\begin{tabular}{|l|c|c|c|c|}
\hline \multicolumn{1}{|c|}{$\begin{array}{c}\text { Monitoring } \\
\text { Campaign }\end{array}$} & Date & $\begin{array}{c}\text { Period } \\
\text { [hours] }\end{array}$ & $\begin{array}{c}\text { Number } \\
\text { of tours }\end{array}$ & $\begin{array}{c}\text { Visitors } \\
\text { totally }\end{array}$ \\
\hline Campaign I & 28-30 Sept. 2013 & 48 & 16 & 265 \\
\hline Campaign II & 19-21 Oct. 2013 & 48 & 11 & 176 \\
\hline Campaign III & 2-4 Nov. 2013 & 48 & 6 & 124 \\
\hline
\end{tabular}

of temperature differences and checked at the cave door positions. The $\mathrm{CO}_{2}$ concentration was measured in the Gallery Chamber at 1 meter above the cave floor. It was detected by a 2-channel IR-detector FT A600-CO2H (measuring range: 0 to 10,000 ppmv; accuracy: $\pm 50 \mathrm{ppmv}+2$ vol. \% of measured value in the range of 0 to 5000 ppmv; resolution: 1 ppmv or 0.0001 vol. \%) linked to the ALMEMO 2290-4 V5 Ahlborn data logger (Germany). The volume concentrations (in ppmv units) were subsequently recalculated into molar concentration $\left(\mathrm{mol} \mathrm{m}^{-3}\right)$, based on the Ideal Gas Law and given temperature and pressure,

$$
\mathrm{c}_{\mathrm{CO} 2}\left[\mathrm{~mol} \mathrm{~m}^{-3}\right]=\frac{\mathrm{P}}{10^{6} \mathrm{RT}} \mathrm{c}_{\mathrm{CO} 2}[\mathrm{ppmv}]
$$

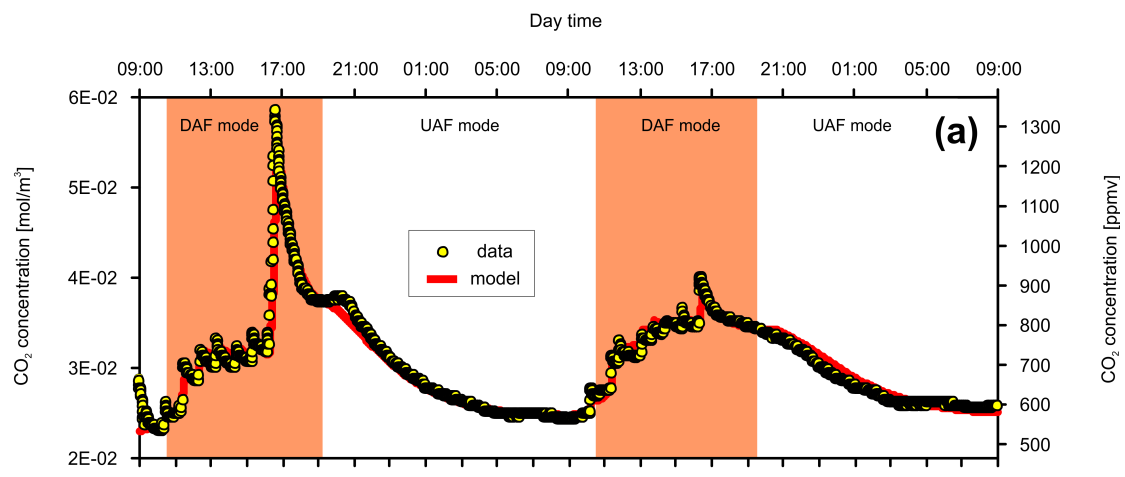

where $\mathrm{P}$ is barometric pressure $[\mathrm{Pa}], \mathrm{R}$ is the universal gas constant $[\mathrm{R}=8.3144621$ $\left.\mathrm{J} \mathrm{kg}^{-1} \mathrm{~K}^{-1}\right]$ and $\mathrm{T}$ is temperature $[\mathrm{K}]$.

The temperature was logged (i) in the exterior, about $50 \mathrm{~m}$ outside the cave, and (ii) inside the cave, about $100 \mathrm{~m}$ from the cave entrance. It was measured by COMET S3120 dataloggers (measuring range from -30 to $+70^{\circ} \mathrm{C}$ with a precision of $\pm 0.4^{\circ} \mathrm{C}$ ) (TR Instruments Inc., Czech Republic).

The variables were logged at 1-minute step (Campaigns 1 and 3) and 2-minute step (Campaign 2). The number of visitors in an individual tour was registered before their entering the cave. The moment of visitor entry into the monitoring site (due to the visitor moving with guide's commentary) was delayed by $33 \pm 0.1$ minutes. The length of stay in the site was 5-20 minutes (8.1 $\pm 5.9 \mathrm{~min}$ on average), based on the guide's commentary and visitor number. The initial time of interaction of visitors with the cave environment and the length of stay were finely tuned so that they were consistent with the $\mathrm{CO}_{2}$ concentration peak. The sensitivity analysis was conducted using the program TopRank 6 (2014).

\section{Monitoring Campaign I}

During Campaign I, covering a total of 48 hours (see Table 1 for details), the monitoring was conducted at a temperature difference, $\Delta \mathrm{T}=\mathrm{T}_{\text {external }}-\mathrm{T}_{\text {cave }}$, ranging between -8.8 and $4.9^{\circ} \mathrm{C}$ (Fig. 2c). Two ventilation modes were identified/predicted: (1) downward airflow ventilation mode (DAF) at positive $\Delta \mathrm{T}$ and (2) upward airflow ventilation mode (UAF) at negative $\Delta \mathrm{T}$. The $\mathrm{CO}_{2}$ concentrations in the chamber varied in a wide range number of visitors (Fig. 2a). During the DAF modes, enhanced $\mathrm{CO}_{2}$ concentrations of about $3.45 \times 10^{-2} \mathrm{~mol} \mathrm{~m}^{-3}$ (800 ppmv) on average were registered. Sharp peaks of the values superimposed on "natural" $\mathrm{CO}_{2}$ levels correspond very well to attendance and represent the anthropogenic impact on the $\mathrm{CO}_{2}$ concentrations in the chamber. The heights of peaks corresponded to (i) the number of visitors in individual tours and (ii) staying period in the chamber. In the case of maximum attendance (52 visitors), the peak $\mathrm{CO}_{2}$ concentration reached up to $5.83 \times 10^{-2} \mathrm{~mol} \mathrm{~m}^{-3}$ (1350 ppmv). During the UAF mode, no visitors stayed in the cave. The $\mathrm{CO}_{2}$ concentrations decreased to $2.50 \times 10^{-2} \mathrm{~mol} \mathrm{~m}^{-3}$ (578 ppmv) on average.

\section{Monitoring Campaign II}

This 48-hour campaign (see Table 1) ran at a temperature difference $\Delta \mathrm{T}$ varying from -9.8 to $10.4^{\circ} \mathrm{C}$ (Fig. 3c). The $\mathrm{CO}_{2}$ concentrations varied depending on the temperature difference (DAF mode or UAF mode) and the number of visitors (Fig. 3a). During depending on the temperature difference and the
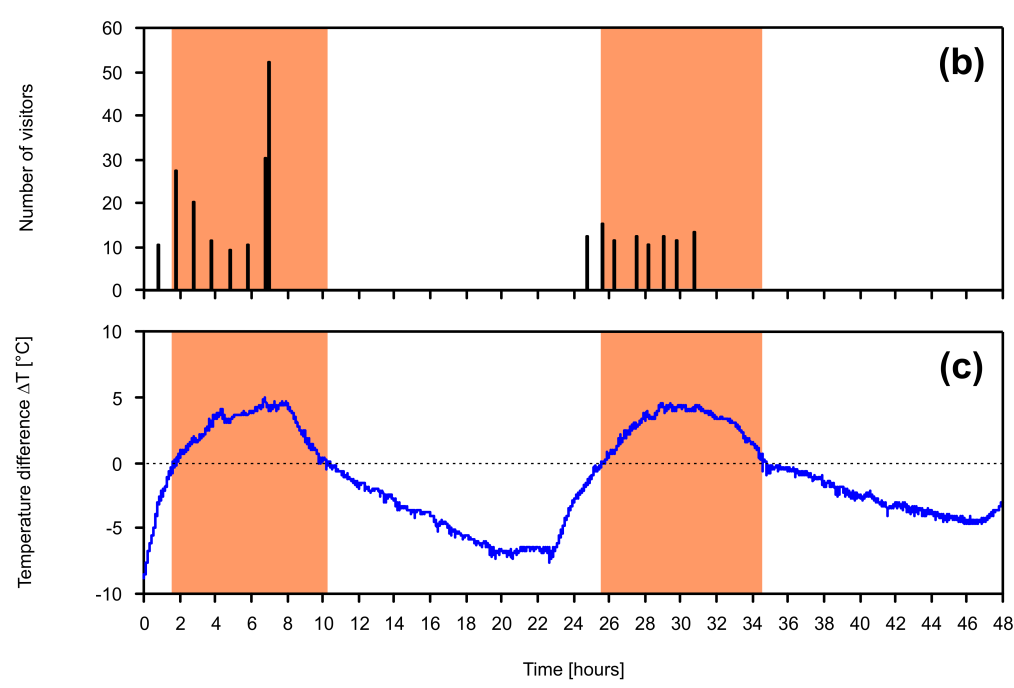

Fig. 2. Monitoring of Campaign I (28-30 September 2013; Gallery Chamber, Balcarka Cave). There are data on $\mathrm{CO}_{2}$ concentrations (the red line represents modeled curve) (a), visitor numbers (b), and temperature difference $\Delta \mathrm{T}$ (c). See text for details. 
Day time
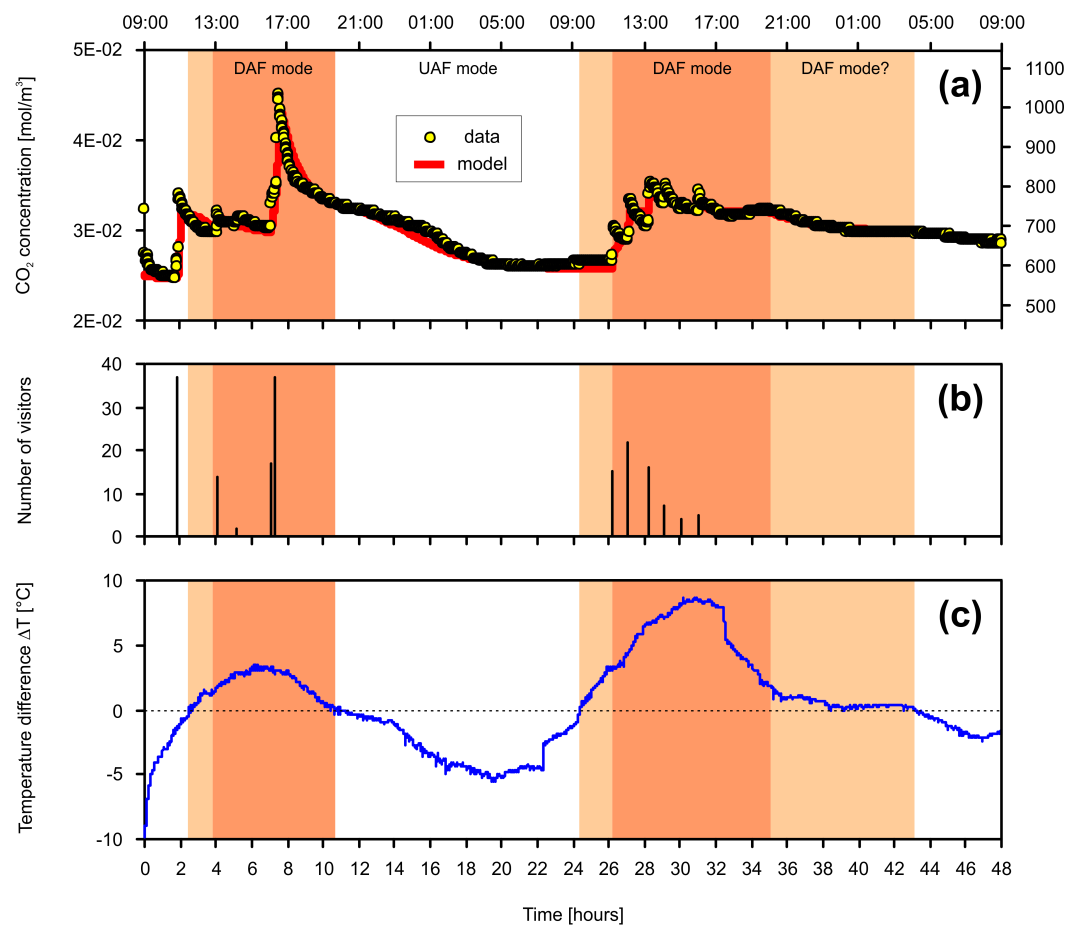

Fig. 3. Monitoring of Campaign II (19-21 October 2013; Gallery Chamber, Balcarka Cave). There are data on $\mathrm{CO}_{2}$ concentrations (the red line represents modeled curve) (a), visitor numbers $(b)$, and temperature difference $\Delta T(c)$. See text for details.

the DAF modes, natural $\mathrm{CO}_{2}$ concentrations varied about $3.00 \times 10^{-2} \mathrm{~mol} \mathrm{~m}^{-3}$ (700 ppmv). The peak values corresponding to 37 visitors reached up to $4.52 \times 10^{-2}$ mol $\mathrm{m}^{-3}$ (1040 ppmv). During the UAF mode (without visitors), the $\mathrm{CO}_{2}$ concentrations decreased to $2.60 \times 10^{-2} \mathrm{~mol} \mathrm{~m}^{-3}$ (600 ppmv).

\section{Monitoring Campaign III}

This 48-hour campaign (see Table 1) ran at a temperature difference $\Delta \mathrm{T}$ ranging from -8.7 to $1.4^{\circ} \mathrm{C}$ (Fig. 4c). The resulting $\mathrm{CO}_{2}$ concentrations in the chamber varied in a narrow range depending on the temperature difference and the number of

$$
\text { Day time }
$$
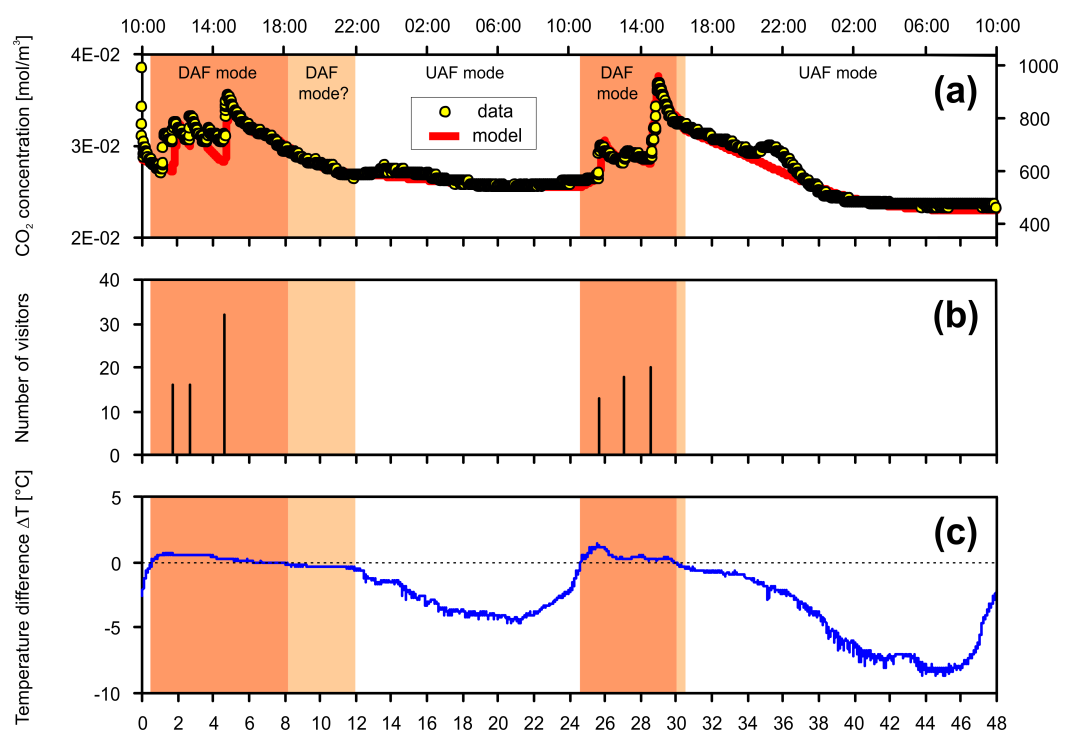

Time [hours]

Fig. 4. Monitoring of Campaign III (2-4 November 2013; Gallery Chamber, Balcarka Cave). There are data on $\mathrm{CO}_{2}$ concentrations (the red line is modeled curve) (a), visitor numbers (b), and temperature difference $\Delta \mathrm{T}$ (c). See text for details. visitors (Fig. 4a). During the DAF modes, natural $\mathrm{CO}_{2}$ concentrations varied about $3.00 \times 10^{-2} \mathrm{~mol} \mathrm{~m}^{-3}$ (693 ppmv) on average. The peak values (at 32 visitors) reached up to $3.68 \times 10^{-2} \mathrm{~mol} \mathrm{~m}^{-3}$ (850 ppmv). During the UAF mode, when no visitors were in the cave, $\mathrm{CO}_{2}$ concentrations decreased to $2.50 \mathrm{x} \quad 10^{-2} \mathrm{~mol} \mathrm{~m}^{-3}$ (578 ppmv).

\section{DATA ANALYSIS}

To evaluate the significant variables/ parameters driving the $\mathrm{CO}_{2}$ concentrations and to better understand the relations between them, a dynamic model was proposed that would simulate the evolution of $\mathrm{CO}_{2}$ levels in the chamber. The model is based on the idea that the instantaneous $\mathrm{CO}_{2}$ concentrations are given by balancing all the $\mathrm{CO}_{2}$ fluxes into/out of the chamber. The conceptual model is depicted in Fig. 5. It consists of three reservoirs, the chamber of interest and two further adjacent spaces, and six fluxes among them: (1) the direct net natural flux into the Gallery Chamber from its overburden, $j_{N}$ (associated with e.g. direct diffusion of $\mathrm{CO}_{2}$ from soils/epikarst through the chamber roof and/or dripwater degassing), (2) the anthropogenic flux $j_{\mathrm{A}}$ (stemming from a person exhaling), (3) the advective input flux $j$ in from an adjacent cave space (driven by ventilation), (4) the advective output flux from the chamber $j_{\text {adv }}^{\text {out }}$ (driven by ventilation), (5) the diffusive input flux from an adjacent space $j_{\text {dif }}^{\text {in }}$, and (6) the diffusive output flux out of the chamber $j_{\text {dif }}^{\text {out }}$. Note that the advective input/output fluxes from/into adjacent spaces changed with each other with switching of the ventilation mode. The fluxes heading into the reservoir of interest (Gallery Chamber) are taken as positive, the fluxes heading out of the reservoir are negative. The total $\mathrm{CO}_{2}$ flux into the reservoir, $\mathrm{j}\left[\mathrm{mol} \mathrm{s}^{-1}\right]$, is given by the sum of all individual fluxes,

$$
\mathrm{j}=\frac{\mathrm{dn}_{\mathrm{CO} 2}}{\mathrm{dt}}=\frac{\mathrm{Vdc}}{\mathrm{dt}}=\sum_{\mathrm{i}} \mathrm{j}_{\mathrm{i}}
$$

where $\mathrm{n}_{\mathrm{CO} 2}$ is the total content of carbon dioxide in the chamber atmosphere [mol], $\mathrm{t}$ is time $[\mathrm{s}], \mathrm{V}$ is the chamber volume $\left[\mathrm{m}^{3}\right]$, $c$ is instantaneous $\mathrm{CO}_{2}$ concentration in the chamber atmosphere $\left[\mathrm{mol} \mathrm{m}^{-3}\right]$, and $\mathrm{j}_{\mathrm{i}}$ are fluxes [ $\mathrm{mol} \mathrm{s}^{-1}$.

The direct flux $\mathrm{j}_{\mathrm{N}}$ was presumed to be constant during monitoring; it was found as one of the model parameters.

Anthropogenic $\mathrm{CO}_{2}$ flux, $\mathrm{j}_{\mathrm{A}}$, was quantified as

$$
\mathrm{j}_{\mathrm{A}}=\mathrm{k}_{\mathrm{A}} \mathrm{A}
$$

where $\mathrm{k}_{\mathrm{A}}$ is a constant representing an anthropogenic personal flux [mol s$\left.{ }^{-1}\right]$ and $\mathrm{A}$ is the attendance [number of visitors]. 

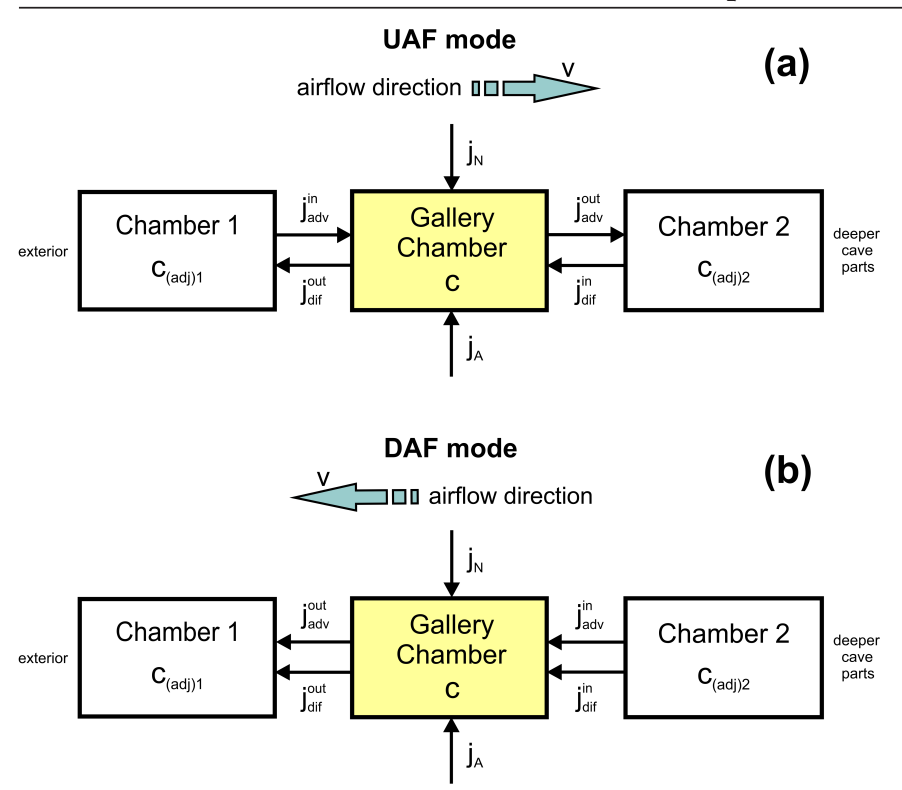

Fig. 5. Conceptual model of $\mathrm{CO}_{2}$ dynamics in the atmosphere of the Gallery Chamber during the DAF ventilation mode (a) and UAF ventilation mode (b).

The advective fluxes, $j_{\text {adv }}^{\text {in }}$ and jadv, respectively, were expressed as a function of concentrations and airflows:

and

$$
\mathrm{j}_{\mathrm{adv}}^{\mathrm{in}}=\mathrm{vc}_{\mathrm{adj}}
$$

$$
\mathrm{j}_{\text {adv }}^{\text {out }}=-\mathrm{v} \mathrm{C}
$$

where $\mathrm{v}$ is the volumetric velocity of airflow through the cave chamber $\left[\mathrm{m}^{3} \mathrm{~s}^{-1}\right], \mathrm{c}$ is $\mathrm{CO}_{2}$ concentration in the chamber $\left[\mathrm{mol} \mathrm{\textrm {m } ^ { - 3 }}\right.$, and $c_{\text {adj }}$ is $\mathrm{CO}_{2}$ concentration in the relevant adjacent cave space serving as a sourcing reservoir $\left[\mathrm{mol} \mathrm{m}^{-3}\right]$. As $\mathrm{c}_{\text {adj }}$, $\mathrm{c}_{\mathrm{adj}}^{(2)}$ was applied for the DAF ventilation mode and $c_{a d j}^{(1)}$ was used for the UAF mode. Based on Faimon \& Lang (2013), the volumetric airflow was calculated from temperature differences,

$$
\mathrm{v}=\mathrm{k}_{\Delta \mathrm{T}} \sqrt{|\Delta \mathrm{T}|}
$$

where $\Delta \mathrm{T}=\mathrm{T}_{\text {exterior }}-\mathrm{T}_{\text {cave }}\left[{ }^{\circ} \mathrm{C}\right]$ and $\mathrm{k}_{\Delta \mathrm{T}}$ is a proportionality constant $\left[\mathrm{m}^{3} \mathrm{~s}^{-1} \mathrm{deg}^{-1 / 2}\right]$.

The input and output diffusive fluxes, $\mathrm{j}_{\text {dif }}^{\text {in }}$, and jout dif respectively, were expressed as

$$
j_{d i f}^{\text {in }}=\frac{D ~ S}{L}\left(c_{d \mathrm{djj}}^{(2)}-c\right)
$$

and

$$
\mathbf{j}_{\mathrm{dif}}^{\text {out }}=-\frac{\mathrm{DS}}{\mathrm{L}}\left(\mathrm{c}-\mathrm{c}_{\mathrm{adj}}^{(1)}\right)
$$

where $\mathrm{D}$ is a diffusion coefficient of $\mathrm{CO}_{2}$ in the cave atmosphere $\left[\mathrm{m}^{2} \mathrm{~s}^{-1}\right], \mathrm{S}$ is the cave cross-section $\left[\mathrm{m}^{2}\right]$, and $\mathrm{L}$ is the distance, for which the concentration gradient, $\Delta \mathrm{c}[\mathrm{m}]$, is given. Eqns. (7) and (8) are relevant for both the DAF and UAF modes.

Based on expected reasonable values of parameters, $\mathrm{D} \sim 1.36 \times 10^{-5} \mathrm{~m}^{2} \mathrm{~s}^{-1}$ (Welty et al., 2008), $\mathrm{S} \sim 10 \mathrm{~m}^{2}$, $\mathrm{L} \sim 100 \mathrm{~m}, \mathrm{v} \sim 0.04 \mathrm{~m}^{3} \mathrm{~s}^{-1}, \mathrm{~V} \sim 150 \mathrm{~m}^{3}, \mathrm{c}_{\mathrm{adj}}^{(1)} \sim 1.7 \times 10^{-2}$ $\mathrm{mol} \mathrm{m}{ }^{-3}$, c $\sim 3-6 \times 10^{-2} \mathrm{~mol} \mathrm{~m}^{-3}$, cadj $\sim 2-4 \times 10^{-2} \mathrm{~mol}$ $\mathrm{m}^{-3}$, the advective fluxes vary in the range of $(1.1-1.5)$ x $10^{-3} \mathrm{~mol} \mathrm{~s}^{-1}$, whereas the diffusive fluxes do not reach the values of $4.8 \times 10^{-8} \mathrm{~mol} \mathrm{~s}^{-1}$.

Inserting all the fluxes into eqn. (2) and rearranging gives

$$
\frac{d c}{d t}=\frac{k_{A} A}{V}+\frac{j_{N}}{V}+\frac{k_{\Delta T} \sqrt{|\Delta T|}}{V}\left(c_{a d j}^{(2)}-c\right)+\frac{D S}{L V}\left(c_{a d j}^{(2)}-2 c+c_{a d j}^{(1)}\right)
$$

for the DAF ventilation mode. Eqn. (9) changes into

$$
\frac{\mathrm{dc}}{\mathrm{dt}}=\frac{\mathrm{k}_{\mathrm{A}} \mathrm{A}}{\mathrm{V}}+\frac{\mathrm{j}_{\mathrm{N}}}{\mathrm{V}}+\frac{\mathrm{k}_{\Delta \mathrm{T}} \sqrt{|\Delta \mathrm{T}|}}{\mathrm{V}}\left(\mathrm{c}_{\mathrm{adj}}^{(1)}-\mathrm{c}\right)+\frac{\mathrm{DS}}{\mathrm{LV}}\left(\mathrm{c}_{\mathrm{adj}}^{(2)}-2 \mathrm{c}+\mathrm{c}_{\mathrm{adj}}^{(1)}\right)
$$

in the case of the UAF mode, due to change in the input advective flux $\mathrm{j}_{\mathrm{adv}}^{\text {in }}$.

For both the ventilation modes, eqns. (9) and (10) were solved numerically. The little significant diffusive fluxes (the last terms in eqns. 9 and 10) were ignored in modeling for simplicity. Initially, values of the model parameters $\left(j_{N}, c_{a d j}, k_{A}, k_{\Delta T}\right.$ ) were roughly set by trial and error so that the model curve best fit the data set. Important criteria for such fitting were (1) correspondence of data with the model at $\Delta \mathrm{T}$ maxima/ minima and at $\Delta \mathrm{T}=0$ in the periods without visitors and (2) heights of the $\mathrm{CO}_{2}$ peaks at visitor presence. Consecutively, detail values of the parameters were exactly determined by the least square method. The loss function was minimized by the Levenberg-Marquardt method (Marquardt, 1963). Results of the modeling are presented in Figs. 2, 3, and 4 as thick red lines; the found regression parameters are given in Table 2.

Table 2. Regression parameters resulting from the modeling of individual monitoring campaigns (Gallery Chamber, Balcarka Cave).

\begin{tabular}{|c|c|c|c|}
\cline { 2 - 4 } \multicolumn{1}{c|}{} & \multicolumn{3}{c|}{ Values } \\
\hline Parameters & Campaign 1 & Campaign 2 & Campaign 3 \\
\hline $\mathrm{j}_{\mathrm{N}}\left[\mathrm{mol} \mathrm{s}^{-1}\right]$ & $6.67 \times 10^{-6}$ & $1.67 \times 10^{-6}$ & $5.00 \times 10^{-6}$ \\
\hline $\mathrm{c}_{\text {adj DAF1 }}\left[\mathrm{mol} \mathrm{m}^{-3}\right]$ & $3.00 \times 10^{-2}$ & $2.95 \times 10^{-2}$ & $2.65 \times 10^{-2}$ \\
\hline $\mathrm{c}_{\text {adj DAF2 }}\left[\mathrm{mol} \mathrm{m}^{-3}\right]$ & $3.30 \times 10^{-2}$ & $3.20 \times 10^{-2}$ & $2.70 \times 10^{-2}$ \\
\hline $\mathrm{c}_{\text {adj UAF1 }}\left[\mathrm{mol} \mathrm{m}^{-3}\right]$ & $2.43 \times 10^{-2}$ & $2.40 \times 10^{-2}$ & $2.50 \times 10^{-2}$ \\
\hline $\mathrm{c}_{\text {adj UAF2 }}\left[\mathrm{mol} \mathrm{m}^{-3}\right]$ & n.u. & $2.55 \times 10^{-2}$ & $2.25 \times 10^{-2}$ \\
\hline $\mathrm{c}_{\text {adj UAF3 }}\left[\mathrm{mol} \mathrm{m}^{-3}\right]$ & n.u. & $2.80 \times 10^{-2}$ & n.u. \\
\hline $\mathrm{k}_{\mathrm{A}}\left[\mathrm{mol} \mathrm{s}^{-1}\right]$ & $6.67 \times 10^{-5}$ & $4.00 \times 10^{-5}$ & $5.33 \times 10^{-5}$ \\
\hline $\mathrm{k}_{\triangle \mathrm{T} \text { DAF }}\left[\mathrm{m}^{3} \mathrm{~s}^{-1} \mathrm{deg}^{-1 / 2}\right]$ & $1.50 \times 10^{-2}$ & $1.67 \times 10^{-2}$ & $4.83 \times 10^{-2}$ \\
\hline $\mathrm{k}_{\triangle \mathrm{T} \text { UAF }}\left[\mathrm{m}^{3} \mathrm{~s}^{-1} \mathrm{deg}^{-1 / 2}\right]$ & $7.30 \times 10^{-3}$ & $7.47 \times 10^{-3}$ & $5.83 \times 10^{-3}$ \\
\hline
\end{tabular}
n.u. - not used

The $\mathrm{c}_{\mathrm{adj}}$ concentrations varied in the range of (2.65-3.30) x $10^{-2} \mathrm{~mol} \mathrm{~m}^{-3}$ (i.e., 620-770 ppmv) during the DAF mode and (2.25-2.8) x 10-2 $\mathrm{mol} \mathrm{m}^{-3}$ (530-660 ppmv) during the UAF mode. The $\mathrm{k}_{\Delta \mathrm{T}}$ values were determined in the range of (1.50-4.83) $\times 10^{-2} \mathrm{~m}^{3} \mathrm{~s}^{-1} \mathrm{deg}^{-1 / 2}$ (DAF mode) and (5.83-7.47) x 10 $0^{-3} \mathrm{~m}^{3} \mathrm{~s}^{-1} \mathrm{deg}^{-1 / 2}$ (UAF mode). The calculated advective fluxes, $j_{\text {adv }}$, (see Table 3 ) were consistent with those (1.1-1.5) $\times 10^{-3} \mathrm{~mol} \mathrm{~s}^{-1}$ estimated former.

The $k_{\mathrm{A}}$ values were found in the narrow range of (4.00-6.67) x 10-5 $\mathrm{mol} \mathrm{s}^{-1}$ (Table 2). Based on eqn. (6) and the number of visitors (Fig. 2-4), the instantaneous anthropogenic $\mathrm{CO}_{2}$ fluxes, $\mathrm{j}_{\mathrm{A}}$, varied in the ranges: $6.0 \times 10^{-4}$ to $3.5 \times 10^{-3} \mathrm{~mol} \mathrm{~s}^{-1}$ (campaign I), $1.2 \times 10^{-4}$ to $1.5 \times 10^{-3} \mathrm{~mol} \mathrm{~s}^{-1}$ (campaign II), and $6.9 \times 10^{-4}$ to $1.7 \times 10^{-3} \mathrm{~mol} \mathrm{~s}^{-1}$ (campaign III) (Table 3). 
Table 3. Overview of $\mathrm{CO}_{2}$-fluxes based on modeling (Gallery Chamber, Balcarka Cave).

\begin{tabular}{|l|c|c|c|}
\hline \multicolumn{1}{|c|}{ Flux } & Campaign 1 & Campaign 2 & Campaign 3 \\
\hline $\mathrm{j}_{\mathrm{A}}\left[\mathrm{mol} \mathrm{s}^{-1}\right]$ & $6.0 \times 10^{-4}$ to $3.5 \times 10^{-3}$ & $1.2 \times 10^{-4}$ to $1.5 \times 10^{-3}$ & $6.9 \times 10^{-4}$ to $1.7 \times 10^{-3}$ \\
\hline $\mathrm{j}_{\text {adv }}{ }^{\text {(in) }}\left[\mathrm{mol} \mathrm{s}^{-1}\right]$ & up to $1.1 \times 10^{-3}$ & up to $1.5 \times 10^{-3}$ & up to $1.3 \times 10^{-3}$ \\
\hline $\mathrm{j}_{\text {dif }}\left[\mathrm{mol} \mathrm{s}^{-1}\right]$ & up to $4.8 \times 10^{-8}$ & up to $2.7 \times 10^{-8}$ & up to $1.6 \times 10^{-8}$ \\
\hline
\end{tabular}

Direct natural flux $\left(\mathrm{j}_{\mathrm{N}}\right)$ varied in the range of (1.67-6.67) $\times 10^{-6} \mathrm{~mol} \mathrm{~s}^{-1}$. All fluxes are summarized in Tables 2 and 3 . The chamber total volume $\mathrm{V} \sim 150 \mathrm{~m}^{3}$ was used for modeling.

The maximum reachable $\mathrm{CO}_{2}$ concentration under given conditions is consistent with the steady state, at which the change of concentration in the chamber is zero, $\mathrm{dc} / \mathrm{dt}=0$. For the DAF ventilation mode, during which visitors are in the cave, eqn. (9) yields

$\frac{\mathrm{k}_{\mathrm{A}} \mathrm{A}}{\mathrm{V}}+\frac{\mathrm{j}_{\mathrm{N}}}{\mathrm{V}}+\frac{\mathrm{k}_{\Delta \mathrm{T}} \sqrt{|\Delta \mathrm{T}|}}{\mathrm{V}}\left(\mathrm{c}_{\mathrm{adj}}^{(2)}-\mathrm{c}^{\mathrm{ss}}\right)+\frac{\mathrm{DS}}{\mathrm{LV}}\left(\mathrm{c}_{\mathrm{adj}}^{(2)}-2 \mathrm{c}^{\mathrm{ss}}+\mathrm{c}_{\text {adj }}^{(1)}\right)=0$

and after rearranging,

$$
c^{\mathrm{ss}}=\frac{\mathrm{j}_{\mathrm{N}} \mathrm{L}+\mathrm{k}_{\mathrm{A}} \mathrm{A} \mathrm{L}+\mathrm{k}_{\Delta \mathrm{T}} \mathrm{L} \sqrt{|\Delta \mathrm{T}|} \mathrm{c}_{\mathrm{adj}}^{(2)}+\mathrm{DS}\left(\mathrm{c}_{\mathrm{adj}}^{(2)}+\mathrm{c}_{\text {adj }}^{(1)}\right)}{\mathrm{k}_{\Delta \mathrm{T}} \mathrm{L} \sqrt{|\Delta \mathrm{T}|}+2 \mathrm{DS}}
$$

where $\mathrm{c}^{\mathrm{ss}}$ is a steady state of $\mathrm{CO}_{2}$ concentration in the chamber $\left[\mathrm{mol} \mathrm{m}^{-3}\right]$.

The effect of the relevant variables $(\Delta T$ and $A)$ and key parameters $\left(\mathrm{j}_{\mathrm{N}}\right.$ and $\left.\mathrm{c}_{\mathrm{adj}}\right)$ on the cave $\mathrm{CO}_{2}$ concentrations was tested by the standard sensitivity analysis. Generally, the method is used for assessing the contribution of individual driving variables/ parameters to the increment/decrement of the dependent variable (see Saltelli et al., 2004). The analysis was applied to eqn. (12), in which the achievable $\mathrm{CO}_{2}$ level, i.e., the steady state concentration, $\mathrm{c}^{\mathrm{ss}}$, is a function of relevant driving variables/parameters. The calculation was based on the average values of the $\mathrm{k}_{\mathrm{A}}=5.3 \times 10^{-5} \mathrm{~mol} \mathrm{~s}^{-1}$ and $\mathrm{k}_{\Delta \mathrm{T}}=2.67 \times 10^{-2} \mathrm{~m}^{3} \mathrm{~s}^{-1} \mathrm{deg}^{-1 / 2}$ (found by modeling) and the values used for the flux estimating ( $\mathrm{D} \sim 1.36 \times 10^{-5} \mathrm{~m}^{2} \mathrm{~s}^{-1}, \mathrm{~S} \sim 10 \mathrm{~m}^{2}, \mathrm{~L} \sim 100 \mathrm{~m}$, $\mathrm{v} \sim 0.04 \mathrm{~m}^{3} \mathrm{~s}^{-1}, \mathrm{~V} \sim 150 \mathrm{~m}^{3}$, and $\mathrm{c}_{\mathrm{adj}}^{(1)} \sim 1.7 \times 10^{-2} \mathrm{~mol} \mathrm{~m}^{-3}$ ). The individual inputs for the analysis covered the range of parameters/variables found by modeling (Table 2). Results of the sensitivity analysis are presented in Fig. 6. During the natural regime without visitors $(A=0)$, the concentrations in adjacent spaces, $c_{\text {adj }}$, have the most significant effect on $\mathrm{CO}_{2}$ levels (Fig. 6a). The effect of the temperature difference $\Delta \mathrm{T}$ and direct natural flux $\left(\mathrm{j}_{\mathrm{N}}\right)$ are either small or almost negligible, respectively. For the regime with visitors, the results are very different: the $\mathrm{CO}_{2}$ levels are extremely affected by $\Delta \mathrm{T}$ (Fig. 6b). The variations in $\Delta \mathrm{T}$ may almost triple the $\mathrm{CO}_{2}$ level in the chamber in comparison with the visitor number (A) and even quadruple in comparison with the adjacent space concentrations, $\mathrm{c}_{\mathrm{adj}}^{(2)}$. The role of the direct natural flux is similarly insignificant as in the regime without visitors. In the case of $\Delta \mathrm{T}>>0$, the effect of $\Delta \mathrm{T}$ diminishes (Fig. 6c).

\section{DISCUSSION}

The natural $\mathrm{CO}_{2}$ concentrations between $2 \times 10^{-2}$ and $3 \times 10^{-2} \mathrm{~mol} \mathrm{~m}^{-3}$ (460 and $700 \mathrm{ppmv}$ ) found in the
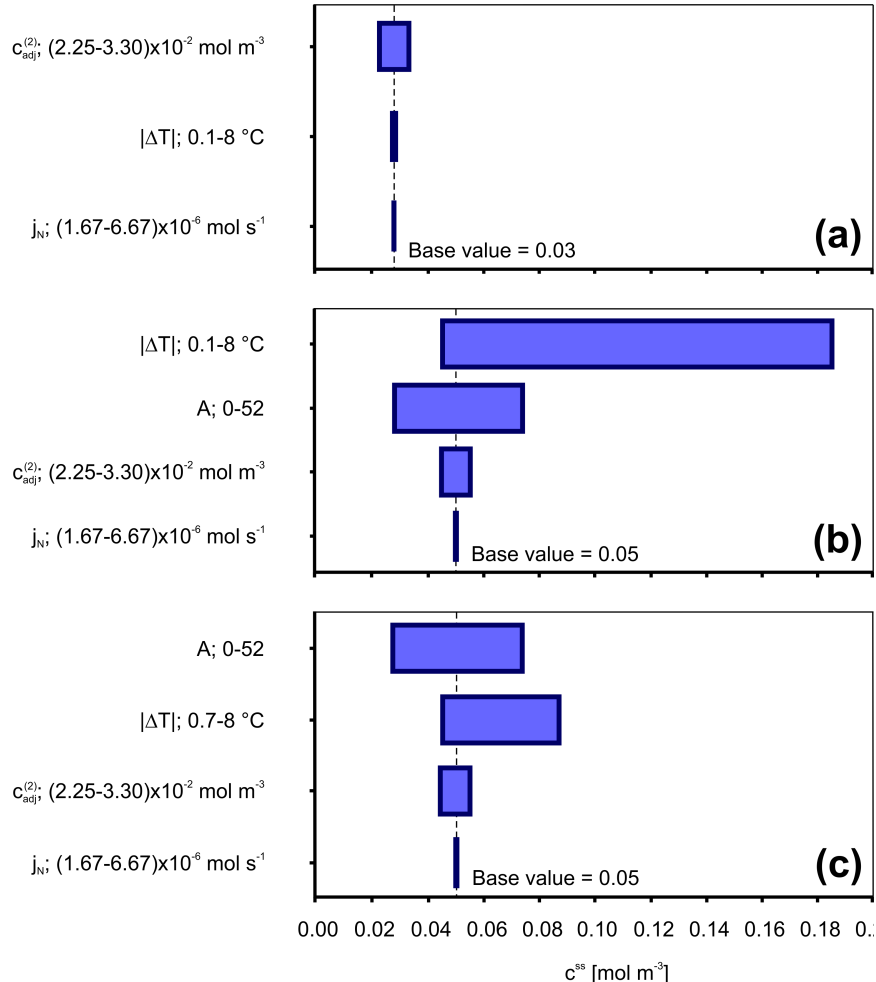

Fig. 6. Sensitivity analysis: evolution of the $\mathrm{CO}_{2}$ steady state concentrations in the cave chamber based on the variation of individual parameters. The case without visitors (a); the case with visitors at different temperature ranges $(b, c)$.

Balcarka Cave are roughly consistent with the values reported by Spötl et al. (2005) for the Obir Caves (Austria), Baldini et al. (2006) for the Ballynamintra Cave (Ireland) or with those measured by Liñan et al. (2008) in the Nerja Cave (Spain). In contrast, these values are substantially lower than the values of $0.24 \mathrm{~mol} \mathrm{~m}^{-3}$ (5,500 ppmv) reported by Buecher (1999) for the Kartchner Caverns (Arizona), $0.36 \mathrm{~mol} \mathrm{~m}^{-3}$ (8,300 ppmv) presented by Ek \& Gewelt (1985) in the Ste-Anne Cave (Belgium), $1.8 \mathrm{~mol} \mathrm{~m}^{-3}$ $(41,500$ ppmv) reported by Bourges et al. (2001) or even $2.68 \mathrm{~mol} \mathrm{~m}^{-3}(62,000 \mathrm{ppmv})$ given by Batiot-Guilhe et al. (2007) (Causse d'Aumelas, France). This comparison indicates that the Balcarka Cave belongs to the caves with rather low $\mathrm{CO}_{2}$ levels. The peak $\mathrm{CO}_{2}$ values up to $6 \times 10^{-2} \mathrm{~mol} \mathrm{~m}^{-3}$ (1,400 ppmv) linked to the anthropogenic impact are comparable with the values referred by Dragovich \& Grose (1990), Faimon et al. (2006) or Benavente et al. (2011). On the other hand, they do not reach the value $\sim 0.1 \mathrm{~mol} \mathrm{~m}^{-3}$ (2,300 ppmv) presented by Milanolo \& Gabrovšek (2009). Nevertheless, the anthropogenic impact on the Balcarka Cave environment may be classified as a standard one in comparison with other visiting caves. During all the monitoring campaigns, the cave persisted in the so-called fall period of limited ventilation (Faimon et al., 2012a). This period follows the summer period of active ventilation that provided enhanced $\mathrm{CO}_{2}$ levels.

\section{Natural influence}

The sensitivity analysis (Fig. 6), the preliminary calculations based on eqns. (3) to (8), and the modeling 
results (Fig. 3-4, Table 2) showed that natural $\mathrm{CO}_{2}$ levels in the chamber (in the case without visitors) are controlled by the advective $\mathrm{CO}_{2}$ fluxes from adjacent cave spaces. These fluxes are a function of (1) $\mathrm{CO}_{2}$ concentrations in these spaces, $\mathrm{c}_{\text {adj }}$, and (2) cave airflows controlled by temperature difference, $\Delta \mathrm{T}=\mathrm{T}_{\text {exterior }}-\mathrm{T}_{\text {cave }}$, (Fig. 6a). Based on airflow direction (controlled by the $\Delta \mathrm{T}$ sign), different $\mathrm{CO}_{2}$ fluxes enter the chamber from different adjacent spaces. The lesser $\mathrm{CO}_{2}$ concentrations are results of the fluxes from the spaces situated below, closer to the cave entrance (operating as an inputting reservoir during the UAF mode, see Fig. 5a). The higher $\mathrm{CO}_{2}$ concentrations are transported by the fluxes from deeper/higher-situated cave spaces (operating as an inputting reservoir during the DAF mode, see Fig. 5b). The concentrations $\mathrm{C}_{\mathrm{adj}}^{(2)}$ are probably derived from soil/epikarstic $\mathrm{CO}_{2}$; it is even conceivable that the concentrations represent the $\mathrm{CO}_{2}$ directly "soaked" from the epikarst. Various sinkholes and shafts filled with porous sediment and representing a section into the karst's vertical profile may serve as the entrances for such transport. Peak values of the $\mathrm{CO}_{2}$ concentrations measured in the soils above the Balcarka Cave reach up to 4,500 ppmv (Faimon et al., 2012c). Under the correction for the drill-hole diameter at monitoring (Blecha \& Faimon, 2014), the peak values could even reach up to $\sim 6,000$ ppmv $\left(2.6 \times 10^{-1} \mathrm{~mol} \mathrm{~m}^{-3}\right)$. Such values should fully cover the concentrations predicted by the model, $\sim 3 \times 10^{-2} \mathrm{~mol} \mathrm{~m}^{-3}$ (Table 2). It should be emphasized that the $\mathrm{CO}_{2}$ concentrations in the adjacent space, $\mathrm{c}_{\mathrm{adj}}^{(2)}$, were not available for direct monitoring because of (1) uncertainty in the airflow path and (2) inaccessibility of such spaces. The $\mathrm{c}_{\mathrm{adj}}^{(1)}$ values predicted by the model, $2.2-2.8 \times 10^{-2} \mathrm{~mol} \mathrm{~m}^{-3}$ (500-650 ppmv) (Table 2) are in good agreement with the values of about $2.3 \times 10^{-2} \mathrm{~mol} \mathrm{~m}^{-3}$ (530 ppmv) ordinarily measured at the entrance passages of the cave. From the $c_{a d j}$ variations during the campaigns and even during individual monitoring periods (Table 2), it is evident that the parameter is not invariant. However, the $8.8 \%$ variation (variation coefficient) during the DAF mode and $7.4 \%$ variation during the UAF mode seem to be reasonable and expectable/acceptable ones considering the capacities of $\mathrm{CO}_{2}$ source and outgoing fluxes.

Similarly to $\mathrm{c}_{\mathrm{adj}}$, data on the actual airflows and its directions were not available. The reason was its extremely low linear velocity and technical difficulties during their monitoring. Therefore, the airflows and their directions were estimated from temperature differences based on eqn. (5) and sign of $\Delta T$, respectively (see Faimon \& Lang, 2013 for details). Based on the regression analysis, the values of $\mathrm{k}_{\Delta \mathrm{T}}$ were found to vary in the range of (5.83-7.47) x $10^{-3} \mathrm{~m}^{3} \mathrm{~s}^{-1} \mathrm{deg}^{-1 / 2}$ for the UAF mode and (1.50-4.83) x $10^{-2} \mathrm{~m}^{3} \mathrm{~s}^{-1} \mathrm{deg}^{-1 / 2}$ for the DAF mode (Table 2). Similar values were found for the Císařská Cave (Moravian Karst) in the UAF mode, but much lesser ones for the same site in the DAF mode (Faimon \& Lang, 2013). In fact, $\mathrm{k}_{\Delta \mathrm{T}}$ is expected to vary with cave geometry, especially the difference in altitudes of entrances, or length and diameters of the conduits.
The switching between DAF and UAF ventilation modes is principally expected at zero $\Delta \mathrm{T}$, when both the cave and external temperatures are balanced. However, the modeling results indicate that the mode switching could be achieved at non-zero $\Delta \mathrm{T}$. This phenomenon was published by, e.g., de Freitas et al. (1982) or Faimon et al. (2012b), who estimated the switching $\Delta \mathrm{T}$ in the range of 0.6 to $1.4^{\circ} \mathrm{C}$. The modeling showed comparable values: the individual ventilation modes in the Gallery Chamber most likely switched at $|\Delta \mathrm{T}|$ ranging from 0.4 to $3.2{ }^{\circ} \mathrm{C}$ (Fig. 3 and 4). This discrepancy may be the result of the nonuniform distribution of temperatures, humidity, and $\mathrm{CO}_{2}$ concentrations throughout the cave (Faimon \& Lang, 2013; Sánchez-Cañete et al., 2013).

The modeling showed that it was potentially suitable for distinguishing the direct net natural fluxes into the chamber from overburden, $\mathrm{j}_{\mathrm{N}}$. Generally, the flux should induce the increment of $\mathrm{CO}_{2}$ levels at/ near zero $\Delta \mathrm{T}$, when the $\mathrm{CO}_{2}$ concentrations in the chamber are not lowered by ventilation. However, the data do not indicate such an effect. The extremely low flux $j_{\mathrm{N}}$ of the orders of $10^{-6} \mathrm{~mol} \mathrm{~s}^{-1}$ was identified (Table 2). The flux is much lower than the advective fluxes (up to $1.5 \times 10^{-3} \mathrm{~mol} \mathrm{~s}^{-1}$ ). This could mean that (1) $\mathrm{CO}_{2}$ fluxes into the cave are distributed ununiformly following predominant paths, and (2) water degassing in the site is not a dominant source. The rather highest $j_{\mathrm{N}}$ value from the observed range that was found during Campaign I (September) might be a residuum of enhanced $\mathrm{CO}_{2}$ production during the end of the summer season. Despite the possible ununiform distribution, the flux $\mathrm{j}_{\mathrm{N}}$ was approximately recalculated into the specific flux normalized to a $1 \mathrm{~m}^{2}$ area. Based on the orthogonal projection plane of the chamber of about $60 \mathrm{~m}^{2}$, such a flux would correspond to the values from $2.8 \times 10^{-8}$ to $1.1 \times 10^{-7} \mathrm{~mol} \mathrm{~m}^{-2} \mathrm{~s}^{-1}$. These values are consistent with $7.59 \times 10^{-8} \mathrm{~mol} \mathrm{~m}^{-2} \mathrm{~s}^{-1}$ presented for the Císařská Cave by Faimon et al. (2006). On the other hand, the value is much lower in comparison with $1 \times 10^{-5} \mathrm{~mol} \mathrm{~m} \mathrm{~m}^{-2} \mathrm{~s}^{-1}$ presented by Milanolo \& Gabrovšek (2009).

\section{Anthropogenic influence}

According to modeling, the peak anthropogenic $\mathrm{CO}_{2}$ flux into the chamber, $\mathrm{j}_{\mathrm{A}}$, reached $3.5 \times 10^{-3} \mathrm{~mol} \mathrm{~s}^{-1}$ depending on the number of visitors. Even though it is a rather higher flux in the modeled system (Table 3), it does not reach the maxima of the natural advective fluxes. The sensitivity analysis showed the extremely strong effect of $\Delta \mathrm{T}$ on the resulting cave $\mathrm{CO}_{2}$ concentrations (Fig. 6b). The reason is that cave ventilation and outputting fluxes are suppressed during the periods at $|\Delta \mathrm{T}| \sim 0^{\circ} \mathrm{C}$, when the chamber $\mathrm{CO}_{2}$ levels are only limited by small diffusive fluxes. From a mathematical point of view, the low value of the denominator in eqn. (12) at $\Delta \mathrm{T}=0^{\circ} \mathrm{C}$ causes an extreme increase in the $\mathrm{c}^{\mathrm{ss}}$ value. However, the time periods when the cave persists at zero $\Delta \mathrm{T}$ are very short, as is visible in the $\Delta \mathrm{T}$ data (Fig. 2c-4c). This short time does not allow neither reaching the steady state concentrations, $c^{s s}$, nor a significant increase 
of the $\mathrm{CO}_{2}$ level in the chamber. For example, data from Campaign I indicate that the $|\Delta \mathrm{T}|$ values are in the range of 0.7 to $8^{\circ} \mathrm{C}$ for $90 \%$ of the time of the monitored period. During this time, the effect of $\Delta \mathrm{T}$ is significantly lower; it is comparable with the visitor effect (see Fig. 6c).

The $k_{\mathrm{A}}$ constant (see Table 1 ) corresponds to an

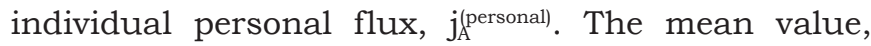

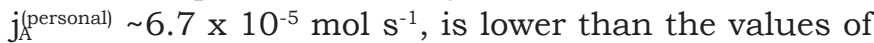
$2.9 \times 10^{-4} \mathrm{~mol} \mathrm{~s}^{-1}$ presented by Faimon et al. (2006) or (2.60-3.35) x $10^{-4} \mathrm{~mol} \mathrm{~s}^{-1}$ reported by Milanolo \& Gabrovšek (2009). In general, factors causing differences in the values may be human age (Tormo et al., 2001; Faimon et al., 2006), activity (Iwamoto et al. 1994), and gender (Sciacca et al. 2002).

To quantify the potential anthropogenic impact, the $\mathrm{CO}_{2}$ steady state, $\mathrm{c}^{\mathrm{ss}}$, was calculated for the maximum number of visitors (Campaign I). If a peak anthropogenic flux $\mathrm{j}_{\mathrm{A}}=3.5 \times 10^{-3} \mathrm{~mol} \mathrm{~s}^{-1}$ is assumed, a steady state concentration of $\mathrm{c}^{\mathrm{ss}} \sim 0.15 \mathrm{~mol} \mathrm{~m}^{-3}$ (3471 ppmv) would be reached. This value is roughly comparable with the value presented by Faimon et al. (2006). It shows that the natural $\mathrm{CO}_{2}$ level could almost be tripled under the condition that visitors were in cave for a sufficiently long period.

The present work should be understood as an attempt to simulate cave $\mathrm{CO}_{2}$ levels based on (1) a limited/ordinary available data set and (2) a general knowledge on the art of cave microclimatology. The reason for limited data are principal difficulties at the direct measuring of (i) $\mathrm{CO}_{2}$ concentrations at the adjacent sites and (ii) cave airflows. Therefore, all the missing parameters, $\mathrm{j}_{\mathrm{N}}, \mathrm{c}_{\mathrm{adj}}, \mathrm{k}_{\mathrm{A}}$, and $\mathrm{k}_{\Delta \mathrm{T}}$, were found indirectly, by modeling. This led to the great fitting of the data by the model on one hand, however, to a limited verification of an inner mechanism of the model by direct measurement on the other hand. Nevertheless, we believe that our approach would be useful for other researchers as a basic tool for the study of cave $\mathrm{CO}_{2}$ dynamics and that the model will be elaborated in greater detail in the future.

\section{CONCLUSIONS}

The evolution of $\mathrm{CO}_{2}$ concentrations was studied in the homothermic zone of the Balcarka Cave, the visiting cave in Moravian Karst (Czech Republic) during the fall period of limited ventilation. The results showed that $\mathrm{CO}_{2}$ levels in the studied cave site were controlled by different factors depending on given conditions in both the exterior and interior. When no visitors were present, the $\mathrm{CO}_{2}$ levels in the chamber were controlled by $\mathrm{CO}_{2}$ fluxes from adjacent cave spaces. These fluxes were controlled by (1) the adjacent spaces' $\mathrm{CO}_{2}$ levels and (2) airflows driven by the temperature difference between the exterior and the cave site. When visitors were present, $\mathrm{CO}_{2}$ levels at the site were significantly influenced by the anthropogenic flux dependent on the number of visitors. The immediate increment of $\mathrm{CO}_{2}$ levels in the chamber depended on the duration of the visit. The model showed that the anthropogenically-impacted steady state concentrations would almost triple the natural $\mathrm{CO}_{2}$ levels when visitors stayed sufficiently on site. This indicates how reducing the period of a tour in the cave could substantially contribute to better protection of the cave environment.

The article represents a case study based on data coming from the late summer and fall, when the cave experienced the so-called "fall period of limited ventilation." This period is characterized by higher natural $\mathrm{CO}_{2}$ levels deeper in the cave that have persisted from an enhanced summer $\mathrm{CO}_{2}$ production. A similar study should be undertaken in the spring period of limited ventilation under the conditions of generally low natural $\mathrm{CO}_{2}$ levels resulting from the winter period of active ventilation. Unfortunately, the cave is closed during the winter season, which did not allow the study of anthropogenic $\mathrm{CO}_{2}$ behavior during the winter period of active ventilation. Nevertheless, further study during the summer period of active ventilation at enhanced natural $\mathrm{CO}_{2}$ levels will be worthwhile. The study results may be useful for better cave management: based on our model, the numbers of visitors in groups and individual intervals between the visitor groups may be determined so that they burden the cave environment less in dependence of seasonal conditions. In general, the work may be of interest to karsologists and environmentalists.

\section{ACKNOWLEDGEMENTS}

The authors wish to thank three anonymous reviewers for valuable comments. Thank you to Peter Blackie and Philippe Labarbe for critically reading the manuscript. The research was supported by funding from the Masaryk University.

\section{REFERENCES}

Baker A. \& Genty D., 1998 - Environmental pressures on conserving cave speleothems: effects of changing surface land use and increased cave tourism. Journal of Environmental Management, 53: 165-175. http://dx.doi.org/10.1006/jema.1998.0208

Baldini J.U.L., Baldini L.M., McDermott F. \& Clipson N., 2006 - Carbon dioxide sources, sinks, and spatial variability in shallow temperate zone caves: Evidence from Ballynamintra Cave, Ireland. Journal of Cave and Karst Studies, 68: 4-11.

Baldini J.U.L., McDermott F., Hoffmann D.L., Richards D.A. \& Clipson N., 2008 - Very high-frequency and seasonal cave atmosphere $\mathrm{PCO}_{2}$ variability: Implications for stalagmite growth and oxygen isotope-based paleoclimate records. Earth and Planetary Science Letters, 272: 118-129.

http://dx.doi.org/10.1016/j.eps1.2008.04.031

Banner J.L., Guilfoyle A., James E.W., Stern L.A. \& Musgrove M., 2007 - Seasonal variations in modern speleothem calcite growth in Central Texas, USA. Journal of Sedimentary Research, 77: 615-622. http://dx.doi.org/10.2110/jsr.2007.065

Batiot-Guilhe C., Seidel J.-L., Jourde, H., Hébrard O. \& Bailly-Comte V., 2007 - Seasonal variations of $\mathrm{CO}_{2}$ and ${ }^{222} \mathrm{Rn}$ in a mediterranean sinkhole - spring (Causse d'Aumelas, SE France). International Journal of Speleology, 36 (1): 51-56. http://dx.doi.org/10.5038/1827-806X.36.1.5 
Benavente J., Vadillo I., Liñan C., Carrasco F. \& Soler A., 2011 - Ventilation effects in a karstic show cave and in its vadose environment, Nerja, Southern Spain. Carbonates and Evaporites, 26: 11-17.

http://dx.doi.org/10.1007/s13146-011-0050-9

Blecha M. \& Faimon J., 2014 - Karst soils: Dependence of $\mathrm{CO}_{2}$ concentrations on pore dimension. Acta Carsologica, 43 (1): 55-64.

Bourges F., Mangin A. \& d’Hulst D., 2001 - Le gaz carbonique dans la dynamique de l'atmosphére des cavités karstiques: l'exemple de l'Aven d'Orgnac (Ardéche). Carbon dioxide in karst cavity atmosphere dynamics: the example of the Aven d'Orgnac (Ardéche). Earth and Planetary Sciences, 333: 685-692.

Bögli A., 1978 - Karsthydrographie und physische Speleologie. Springer, Berlin, 292 p.

Buecher R.H., 1999 - Microclimate study of Kartchner Caverns, Arizona. Journal of Cave and Karst Studies, 61: 108-120.

Cigna A.A., 1968 - An analytical study of air circulation in caves. International Journal of Speleology, 3: 41-54. http://dx.doi.org/10.5038/1827-806X.3.1.3

de Freitas C.R, Littlejohn R.N., Clarkson T.S. \& Kristament I.S., 1982 - Cave climate: assessment of airflow and ventilation. Journal of Climatology, 2: 383-397.

http://dx.doi.org/10.1002/joc.3370020408

Dragovich D. \& Grose J., 1990 - Impact of tourists on carbon dioxide levels at Jenolan Caves, Australia: an examination of microclimatic constraints on tourist cave management. Geoforum, 21: 111-120.

http://dx.doi.org/10.1016/0016-7185(90)90009-U

Dreybrodt W., 1999 - Chemical kinetics, speleothem growth and climate. Boreas, 28: 347-356.

Ek C. \& Gewelt M., 1985 - Carbon dioxide in cave atmospheres. New results in belgium and comparison with some other countries. Earth Surface Processes and Landforms, 10: 173-187.

http://dx.doi.org/10.1002/esp.3290100209

Faimon J., Štelcl J. \& Sas D., 2006 - Anthropogenic $\mathrm{CO}_{2}{ }^{-}$ flux into cave atmosphere and its environmental impact: a case study in the Císařská Cave (Moravian Karst, Czech Republic). Science of the Total Environment, 369: 231-245.

Faimon J., Ličbinská M., Zajíček P. \& Sracek O., 2012a Partial pressures of $\mathrm{CO}_{2}$ in epikarstic zone deduced from hydrogeochemistry of permanent dripws, the Moravian Karst, Czech Republic. Acta Carsologica, 41 (1): 47-57.

Faimon J., Troppová D., Baldík V. \& Novotný R., 2012b Air circulation and its impact on microclimatic variables in the Císařská Cave (Moravian Karst, Czech Republic). International Journal of Climatology, 32: 599-623. http://dx.doi.org/10.1002/joc.2298

Faimon J., Ličbinská M. \& Zajíček P., 2012c - Relationship between carbon dioxide in Balcarka Cave and adjacent soils in the Moravian Karst region of the Czech Republic. International Journal of Speleology, 41 (1): 17-28. http://dx.doi.org/10.5038/1827-806X.41.1.3

Faimon J. \& Lang M., 2013 - Variances in airflows during different ventilation modes in a dynamic $U$-shaped cave. International Journal of Speleology, 42 (2): 115-122. http://dx.doi.org/10.5038/1827-806X.42.2.3

Fairchild I.J., Borsato A., Tooth A.F., Frisia S., Hawkesworth C.J., Huang Y., McDermott F. \& Spiro B., 2000 - Controls on trace element (Sr-Mg) compositions of carbonate cave waters: implications for speleothem climatic records. Chemical Geology, 166: 255-269. http://dx.doi.org/10.1016/S0009-2541(99)00216-8
Fernández-Cortes A., Sanchez-Moral S., Cuezva S., Cañaveras J.C. \& Abella R., 2009 - Annual and transient signatures of gas exchange and transport in the Castañar de Ibor cave (Spain). International Journal of Speleology, 38 (2): 153-162.

http://dx.doi.org/10.5038/1827-806X.38.2.6

Ford T.D. \& Williams P.W., 2007 - Karst Hydrogeology and Geomorphology. Wiley \& Sons, Chicester. 562 p.

Geiger R., 1966 - The climate near the ground. Harvard University Press, Cambridge, 628 p.

Holland H.D., Kirsipu T.V., Huebner J.S. \& Oxburgh U.M., 1964 - On some aspects of the chemical evolution of cave water. Journal of Geology, 72: 36-67.

http://dx.doi.org/10.1086/626964

Iwamoto J., Pendergast D.R., Suzuki H. \& Krasney J.A., 1994 - Effect of graded exercise on nitric oxide in expired air in humans. Respiration Physiology, 97: 333-345. http://dx.doi.org/10.1016/0034-5687(94)90069-8

Kowalczk A.J. \& Froelich P.N., 2010 - Cave air ventilation and $\mathrm{CO}_{2}$ outgassing by radon-222 modeling: How fast do caves breath? Earth and Planetary Science Letters, 289: 209-219.

http://dx.doi.org/10.1016/j.eps1.2009.11.010

Lario J. \& Soler V., 2010 - Microclimate monitoring of Pozalagua Cave (Vizcaya, Spain): application to management and protection of show caves. Journal of Cave and Karst Studies, 72 (3): 169-180.

http://dx.doi.org/10.4311/jcks20091sc0093

Liñán C., Vadillo I. \& Carrasco F., 2008 - Carbon dioxide concentration in air within the Nerja Cave (Malaga, Andalusia, Spain). International Journal of Speleology, 37: 99-106.

http://dx.doi.org/10.5038/1827-806X.37.2.2

Luetscher M. \& Jeannin P.-Y., 2004b - Temperature distribution in karst systems: the role of air and water fluxes. Terra Nova, 16: 344-350.

http://dx.doi.org/10.1111/j.1365-3121.2004.00572.x

Marquardt D.W., 1963 - An Algorithm for Least-Squares Estimation of Nonlinear Parameters. Journal of the Society for Industrial and Applied Mathematics, 11 (2): 431-441.

http://dx.doi.org/10.1137/0111030

Milanolo S. \& Gabrovšek F., 2009 - Analysis of Carbon Dioxide Variations in the Atmosphere of Srednja Bijambarska Cave, Bosna and Herzegovina. BoundaryLayer Meteorology, 131: 479-493.

http://dx.doi.org/10.1007/s10546-009-9375-5

Pflitsch A. \& Piasecki J., 2003 - Detection of an airflow system in Niedzwiedzia (Bear) Cave, Kletno, Poland. Journal of Cave and Karst Studies, 65: 160-173.

Pulido-Bosch A., Martín-Rosales W., López-Chicano M., Rodríguez-Navarro C.M. \& Vallejos A., 1997 - Human impact in a tourist karstic cave (Aracena, Spain). Environmental Geology, 31 (3/4): 142-149. http://dx.doi.org/10.1007/s002540050173

Russell M.J. \& MacLean V.L., 2008 - Management issues in a Tasmanian tourist cave: Potential microclimatic impacts of cave modifications. Journal of Environmental Management, 87: 474-483.

http://dx.doi.org/10.1016/j.jenvman.2007.01.012

Sánchez-Cañete E.P., Serrano-Ortiz P., Domingo F. \& Kowalski A.S., 2013 - Cave ventilation is influenced by variations in the $\mathrm{CO}_{2}$-dependent virtual temperature. International Journal of Speleology, 42 (1): 1-8. http://dx.doi.org/10.5038/1827-806X.42.1.1

Saltelli A., Tarantola S., Campolongo F. \& Ratto M., 2004 - Sensitivity analysis in practice: A guide to assessing scientific models. ( $1^{\text {st }}$ ed.). John Wiley \& Sons, Chichester, 232 p. 
Sciacca J., Forbes W.M., Ashton F.T., Lombardini E., Gamble H.R. \& Schad G.A., 2002 -Response to carbon dioxide by the infective larva of three species of parasiti nematodes. Parasitology International, 51: 53-62.

http://dx.doi.org/10.1016/S1383-5769(01)00105-2

Song L., Wei X. \& Liang F., 2000 - The influences of cave tourism on $\mathrm{CO}_{2}$ and temperature in Baiyun Cave, Hebei, China. International Journal of Speleology, 29 B (1/4): 77-87.

Spötl C., Fairchild I.J. \& Tooth A.F., 2005 - Cave air control on dripwater geochemistry, Obir Caves (Austria): implications for speleothem deposition in dynamically ventilated caves. Geochimica et Cosmochimica Acta, 69 (10): 2451-2468.

http://dx.doi.org/10.1016/j.gca.2004.12.009
TopRank 6, 2014 - Automated "what-if" Analysis for Spreadsheet. Online: http://www.palisade.com/toprank/ [20. 2. 2014]

Tormo R., Bertaccini A., Conde M., Infante D. \& Cura I., 2001 - Methane and hydrogen exhalation in normal children and in laktose malabsorption. Early Human Development, 65: 165-172.

http://dx.doi.org/10.1016/S0378-3782(01)00219-5

White W.B., 1988 - Geomorphology and hydrology of karst terrains. Oxford University Press, New York, 464 p.

Wigley T.M.L. \& Brown M.C., 1971 - Geophysical applications of heat and mass transfer in turbulent pipe flow. Boundary-Layer Meteorology, 1: 300-320. http://dx.doi.org/10.1007/BF02186034

Welty J.R., Wicks C.E., Wilson R.E. \& Rorrer G.L., 2008 - Fundamentals of momentum, heat, and mass transfer. ( $5^{\text {th }}$ ed.). John Wiley \& Sons, Inc., New York, 729 p. 